Available online on 15.03 .2020 at http://jddtonline.info
Open Access to Pharmaceutical and Medical Research
unrestricted non-commercial use, provided the original work is properly cited

Open 2 Access

Research Article

\title{
Formulation and Evaluation of Fixed Dose Combination Tablets of Antifungal Drugs for Candida albicans Resistant to Fluconazole
}

\author{
Bhumika Thakur ${ }^{1 *}$, Shiv Kumar Kushawaha², Vinay Pandit ${ }^{2}$, Mahendra Singh Ashawat ${ }^{2}$, Pravin Kumar ${ }^{2}$ \\ 1 Shiva Institute of B.Pharmacy, Bilaspur, Himachal Pradesh, India-174004 \\ ${ }^{2}$ Laureate Institute of Pharmacy, Kangra, Himachal Pradesh, India-177101
}

\begin{abstract}
Background: The emergence of Candida albicans strains resistant to fluconazole (FLZ) had raised interest on combining other antifungals with FLZ. In vitro and clinical studies had indicated synergistic interaction between terbinafine and FLZ against strains resistant to FLZ and improved therapeutic efficacy. Objective: Formulation and evaluation of fixed dose combination (FDC) tablets of terbinafine HCl (TH) and FLZ for avoidance of resistance and improved therapeutic efficacy against $C$. albicans infections. Method: The compatibility of TH and FLZ together and with excipients was determined by FTIR spectroscopy. A UV-visible spectroscopic Q-absorbance ratio method was developed and validated for linearity, accuracy, precision, LOD and LOQ for simultaneous estimation of TH and FLZ. The FDC tablets was prepared by wet granulation using hydroxy propyl cellulose (1\%,2\%,3\%, 4\% and 5\%) as binder and evaluated for pre-compression and post-compression parameters. Result and Discussion: The TH and FLZ were compatible together and with excipients used in FDC. The linearity range was found to be $0.5-3.0$ $\mu \mathrm{g} / \mathrm{ml}$ and $80-400 \mu \mathrm{g} / \mathrm{ml}$ for TH and FLZ, respectively. Percent RSD was less than 2\% indicating good accuracy and precision for proposed method. The hardness and disintegration time of tablets increased and friability decreased with increased binder concentration. Formulation F2 and F3 showed more than $80 \%$ drug release within 30 minutes. Conclusion: The TH and FLZ were compatible and can be formulated as a FDC tablet. The UV-Visible spectrophotometric method developed for simultaneous estimation was simple, accurate and sensitive.
\end{abstract}

Keywords: Terbinafine, Fluconazole, Q-absorbance, Fixed Dose Combination, Candida albicans

Article Info: Received 03 Jan 2020; Review Completed 10 Feb 2020; Accepted 18 Feb 2020; Available online 15 March 2020

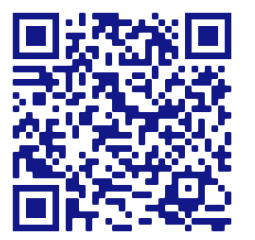

\section{Cite this article as:}

Thakur B, Kushawaha SK, Pandit V, Ashawat MS, Kumar P, Formulation and Evaluation of Fixed Dose Combination Tablets of Antifungal Drugs for Candida albicans Resistant to Fluconazole, Journal of Drug Delivery and Therapeutics. 2020; 10(2):26-36 http://dx.doi.org/10.22270/jddt.v10i2.3905

*Address for Correspondence:

Bhumika Thakur, Shiva Institute of B.Pharmacy, Bilaspur, Himachal Pradesh, India-174004

\section{INTRODUCTION}

Candida albicans is the most important fungal strain accountable for most of the localized and systemic fungal infections ${ }^{1}$. Systemic candidiasis is the leading cause of mycosis-associated mortality in the United States and is globally recognized as a cause of significant morbidity 2 .

Immunocompromised patients, such as AIDS patients or are neutropenic due to cancer therapy, are at specific threat of evolving local $C$. albicans infections, which may become systemic 3,4 . Fluconazole (FLZ) is an orally active triazole agent, well established as a first-line treatment for localized and systemic $C$. albicans infections ${ }^{1}$. In the past decades, advent of resistant $C$. albicans strains to FLZ on long term suppressive therapy has been reported in AIDS patient with oropharyngeal candidiasis 5, 6. An attractive therapeutic option in these circumstances is combining other antifungals with the FLZ for synergistic effect and widened spectrum against FLZ resistant fungal strains. The use of terbinafine an orally and topically active antifungal has been recommended in combination with FLZ for the cases with FLZ resistant $C$. albicans ${ }^{7}$. Terbinafine is act as a fungicidal against a broad spectrum of fungi including dermatophytes, filamentous, dimorphic organisms and some yeast such as Candida parapsilosis 8 .

Synergistic interactions of terbinafine with azoles and other compounds against Candida albicans have been reported by many investigators. Ghonnoum and Elewski 6 had reported the successful treatment of oropharyngeal candidiasis patients with a combination of FLZ and terbinafine who had also FLZ-refractory. In an in vitro study, Barchiesi and colleagues concluded a synergistic interaction between terbinafine and FLZ against $C$. albicans strain with reduced susceptibility to FLZ ${ }^{7}$. The above evidences suggested that combining the terbinafine and FLZ in fixed dose combinations (FDC) can be a better approach for the treatment of cases associated with FLZ resistant $C$. albicans. FDC are dosage forms which contain two or more active 
ingredients in fixed proportions in same formulations. FDC can offer enough advantages as compared to traditional monotherapy like improved patients compliance, simple dosage schedule, greater efficacy compared to monotherapy, reduced adverse events and synergistic effect ${ }^{9}$.

So, in the present research work, fixed dose combination (FDC) tablets of terbinafine hydrochloride (TH) and FLZ has been formulated by wet granulation using hydroxy propyl cellulose (HPC) as a binder and starch as disintegrating agent. During the preformulation studies the compatibility of the TH and FLZ together and with different excipients were evaluated. A UV spectrophotometric method i.e Q-anlysis or Q-absorbance ratio for the simultaneous analysis of TH and FLZ was developed and validated. The ratio of absorbance at two wavelengths is constant for two different concentrations. In this method, the absorption of the two components is measured at two different wavelengths. One being the absorption at $\lambda_{\max }$ of one of the component and other is absorption at iso-absorptive point 10 .

\section{MATERIALS AND METHODS}

Fluconazole and terbinafine $\mathrm{HCl}$ was procured from Lark Pharmaceuticals, Bhiwandi, India as gift sample. HPC, starch, magnesium stearate, talc and lactose were procured from CDH Chemicals, Mumbai.

\subsection{Preformulation studies}

Preformulation studies are carried out in order to determine the physiochemical properties of drug which helps in the design of a safe, efficacious and stable dosage form. The drugs (TH and FLZ) were physically characterized on the basis of color and odor. All the physical characterization were observed and compared with the monograph in official Pharmacopoeia. Melting point of $\mathrm{TH}$ and FLZ was determined by using digital melting point test apparatus.

\subsubsection{Absorption maxima $\left(\lambda_{\max }\right)$ and preparation of} calibration curve

The $\lambda_{\max }$ of $\mathrm{TH}$ was determined in $0.1 \mathrm{~N} \mathrm{HCl}$ by scanning the $3.0 \mu \mathrm{g} / \mathrm{ml}$ solution in range of $400-200 \mathrm{~nm}$ using UV-Visible spectrophotometer (Lab India, Mumbai). The calibration curve of TH was prepared by dissolving $100 \mathrm{mg}$ in small volume of $0.1 \mathrm{~N} \mathrm{HCl}$ and final volume was adjusted up to $100 \mathrm{ml}$ with the same solvent. A series of standard solution of concentrations $0.5,1.0,1.5,2.0,2.5$ and $3.0 \mu \mathrm{g} / \mathrm{ml}$ were prepared and absorbance was measured at $222 \mathrm{~nm}$ against blank using an UV-Visible spectrophotometer.

The $\lambda_{\text {max }}$ of FLZ was determined in $0.1 \mathrm{~N} \mathrm{HCl}$ by scanning the $400 \mu \mathrm{g} / \mathrm{ml}$ solution in range of $400-200 \mathrm{~nm}$ using UV-Visible spectrophotometer. An accurately weighed $100 \mathrm{mg}$ of FLZ was dissolved in small volume of $0.1 \mathrm{~N} \mathrm{HCl}$ in the $100 \mathrm{ml}$ volumetric flask and final volume was adjusted with the same solvent. A series of standard solutions of concentrations $80,120,160,200,240,280,320,360$ and $400 \mu \mathrm{g} / \mathrm{ml}$ of FLZ were prepared. The measurements of absorbance were done at $260 \mathrm{~nm}$ against blank using an UVVisible spectrophotometer.

\subsubsection{Fourier transformed infrared (FTIR) studies of pure drugs}

FTIR spectra of pure drug were observed and analyse by potassium bromide $(\mathrm{KBr})$ press pellet method. Pure drug TH was uniformly mixed with dry powdered $\mathrm{KBr}$ in the ratio of 1:100 and mixture was then compressed into transparent disc under high pressure using special dies. The disc was placed in FTIR spectrophotometer (Shimadzu IR Affinity-1) and spectrum was recorded. Same procedure was followed for FLZ and spectrum was recorded.

ISSN: 2250-1177

\subsubsection{Compatibility study of Drug-drug and drug- excipient by FTIR spectroscopy}

TH and FLZ compatibility, together and with the excipients used in the formulation of tablets was determined by FTIR spectrophotometer. TH and FLZ physical mixture (250 $\mathrm{mg}: 150 \mathrm{mg}$ ) was prepared by triturating them together in a clean and dried mortar-pestle. The one part of above prepared physical mixture and hundred part of FTIR grade $\mathrm{KBr}$ was mixed together properly. Then using $\mathrm{KBr}$ press pellet a thin and transparent pellet was prepared. The FTIR spectrum, of pure TH and FLZ, recorded by $\mathrm{KBr}$ disc method was compared for specific peak positions of different functional groups.

To determine the compatibility of $\mathrm{TH}$ and FLZ with excipients used for formulation of FDC tablets, triturate the TH, FLZ, HPC, starch, talc, magnesium stearate and lactose with ethanol. The prepared physical mixture was dried in a hot air oven to completely remove the ethanol and any traces of moisture at $60^{\circ} \mathrm{C}$ and passed through the BSS number 85 . The FTIR spectrum of the physical mixture was recorded by $\mathrm{KBr}$ disc method and peak positions of important functional groups in pure drugs were compared.

\subsection{Development and validation of simultaneous estimation method for TH and FLZ by UV-Visible spectrophotometer}

Q-Absorbance ratio or Q-Analysis method for simultaneous estimation of TH and FLZ by UV-Visible spectrophotometer was developed and validated $10-12$.

\subsubsection{Standard stock solutions of TH and FLZ}

$100 \mathrm{mg}$ of $\mathrm{TH}$ was dissolved in small volume of $0.1 \mathrm{~N} \mathrm{HCl}$ in $100 \mathrm{ml}$ volumetric flask. The solution was sonicated for 10 minutes and adjusted the final volume with $0.1 \mathrm{~N} \mathrm{HCl}$. From standard stock solution $(1000 \mu \mathrm{g} / \mathrm{ml})$, by pipetting out $1 \mathrm{ml}$ in a $100 \mathrm{ml}$ volumetric flask working stock solution $\quad(10$ $\mu \mathrm{g} / \mathrm{ml}$ ) was prepared and final volume was adjusted with $0.1 \mathrm{~N} \mathrm{HCl}$. Then in series of $10 \mathrm{ml}$ volumetric flasks pipetting out $0.5,1.0,1.5,2.0,2.5$ and $3 \mathrm{ml}$ from working stock solution and volume was made up to the mark with the same solvent. For FLZ standard solution $100 \mathrm{mg}$ of drug was dissolved in small volume of $0.1 \mathrm{~N} \mathrm{HCl}$ in a $100 \mathrm{ml}$ volumetric flask. The solution was sonicated for 10 minutes and final volume adjusted. From above solution 0.8 , 1.2, 1.6, 2.0, 2.4, $2.8,3.2,3.6$ and $4.0 \mathrm{ml}$ were pipetted out in series of $10 \mathrm{ml}$ volumetric flask and final volume was made up with $0.1 \mathrm{~N}$ $\mathrm{HCl}$.

\subsubsection{Selection of wavelength of maximum absorbance} $\left(\lambda_{\max }\right)$

For $3 \mu \mathrm{g} / \mathrm{ml}$ solution of TH pipetting out $3 \mathrm{ml}$ from working stock solution of drug in $10 \mathrm{ml}$ volumetric flask and final volume was adjusted with $0.1 \mathrm{~N} \mathrm{HCl}$. For $400 \mu \mathrm{g} / \mathrm{ml} \mathrm{FLZ}$ solution was prepared by pipetting out $4 \mathrm{ml}$ from standard stock solution in $10 \mathrm{ml}$ volumetric flask and final volume was adjusted up with $0.1 \mathrm{~N} \mathrm{HCl}$. Both the solutions were scanned in the range of $400-200 \mathrm{~nm}$ against blank solution $(0.1 \mathrm{~N} \mathrm{HCl})$ using UV-Visible spectrophotometer.

\subsubsection{Determination of iso-absorptive point}

Iso-absorptive point was determined by preparing $1.5 \mu \mathrm{g} / \mathrm{ml}$ solutions of TH and $200 \mu \mathrm{g} / \mathrm{ml}$ of FLZ and by scanning in the range of $400-200 \mathrm{~nm}$ against $0.1 \mathrm{~N} \mathrm{HCl}$ as blank using an UVVisible spectrophotometer. An overlain spectrum of TH and FLZ was found and iso-absorptive point was determined.

\subsubsection{Determination of Linearity range}


Linearity range of $\mathrm{TH}$ was determined by preparing different concentrations i.e. $0.5,1.0,1.5,2.0,2.5$ and $3.0 \mu \mathrm{g} / \mathrm{ml}$ from working standard solution and at $222 \mathrm{~nm}$ and $239 \mathrm{~nm}$ absorbance was taken against $0.1 \mathrm{~N} \mathrm{HCl}$ as a blank. Linearity curve was plotted between concentration vs. absorbance. Linearity of FLZ was determined by preparing different concentrations $160,200,240,300,360$ and $400 \mu \mathrm{g} / \mathrm{ml}$ were prepared from standard stock solution and absorbance was measured at $222 \mathrm{~nm}$ and $239 \mathrm{~nm}$ against $0.1 \mathrm{~N} \mathrm{HCl}$ as a blank. Than linearity curve was plotted between concentration vs. absorbance.

\subsubsection{Determination of Accuracy}

To determine the accuracy of the proposed method 2.0, 2.5 and $3.0 \mu \mathrm{g} / \mathrm{ml}$; and 240,300 and $360 \mu \mathrm{g} / \mathrm{ml}$ solutions were prepared for TH and FLZ, respectively. These were the three different levels $80 \%, 100 \%$ and $120 \%$ by considering $2.5 \mu \mathrm{g} / \mathrm{ml}$ and $300 \mu \mathrm{g} / \mathrm{ml}$ as $100 \%$ for $\mathrm{TH}$ and FLZ, respectively. The recovery study was performed three times at each level.

\subsubsection{Determination of Precision}

\subsubsection{Intermediate Precision (Inter-day and Intra-day precision)}

The solutions of same concentrations were prepared as in the determination of accuracy. Inter-day precision both the drugs were analyzed individually daily once for three days at specified wavelengths as above. Intra-day precision was determined by analyzing TH and FLZ individually for three times in the same day at the wavelength $222 \mathrm{~nm}$ and 239 $\mathrm{nm}$. The standard deviation and relative standard deviation were calculated.

\subsubsection{Repeatability}

In repeatability, $3.0 \mu \mathrm{g} / \mathrm{ml}$ and $300 \mu \mathrm{g} / \mathrm{ml}$ solutions were prepared for TH and FLZ, respectively. The measurement of absorbance was taken at $222 \mathrm{~nm}$ and $239 \mathrm{~nm}$ against $0.1 \mathrm{~N}$ $\mathrm{HCl}$ as a blank. The experiment was done six times. The standard deviation and relative standard deviation was calculated.

\subsubsection{Reproducibility}

The absorbance was measured by two analysts and values obtained were evaluated using t-test to verify their reproducibility. $2.0 \mu \mathrm{g} / \mathrm{ml}$ and $300 \mu \mathrm{g} / \mathrm{ml}$ solutions were prepared from stock solutions separately of TH and FLZ, respectively and analyzed by one analyst (analyst 1) at 222 $\mathrm{nm}$ and $239 \mathrm{~nm}$. Same solutions were prepared by another analyst (analyst 2) and values obtained were evaluated using t-test to verify their reproducibility.

\subsubsection{Limit of Detection (LOD)}

The LOD is defined as in a sample lowest concentration of a drug that can be detected, but not necessarily quantified, under the given conditions of the test. LOD was calculated from the obtained data from the linearity studies. The slope of the linearity plot was determined and calculated by formula given below.

$\mathrm{LOD}=3.3(\mathrm{~S} / \mathrm{b})$

Where,

$\mathrm{S}=$ Standard deviation of the residuals around the regression line.

$$
\mathrm{b}=\text { Slope of the regression line. }
$$

\subsubsection{Limit of Quantitation (LOQ)}

The LOQ is defined as the lowest concentration of a drug in a sample that can be determined with acceptable accuracy and precision under the given conditions of test. Limit of quantitation can be calculated from standard deviation of the response and slope using formula given below.

\section{$L O Q=10(S / b)$}

Where,

$\mathrm{S}=$ Standard deviation of the residuals around the regression line.

$$
\mathrm{b}=\text { Slope of the regression line. }
$$

\subsection{Formulation and Evaluation of FDC tablets}

\subsubsection{Formulation of granules}

For the formulation of FDCs tablets wet granulation method was used and to prepare granules, HPC and starch were used as binder and disintegrant respectively. Talc, magnesium stearate and lactose were used as glidant, lubricant and diluents, respectively (Table No. 1). Firstly TH, FLZ, HPC, starch and lactose were passed through British Standard Sieve (BSS) 60. Then TH, FLZ, HPC, lactose and half of the starch were mixed uniformly and sufficient quantity of distilled water was added with continuous mixing to obtain wet dough mass. The wet mass was shifted through BSS 10 and dried in hot air oven at $60^{\circ} \mathrm{C}$ till moisture content was achieved in the range of $1.5-2 \%$. The dried mass was then passed through the BSS 16/44. The granules which were retained on the BSS 44 were considered coarse granules and the granules which passed through BSS 44 are considered as fines. To the granules, remaining starch, talc and magnesium stearate previously passed through BSS 80 were mixed uniformly.

Table No. 1 Formulation formula for granules using HPC as binder

\begin{tabular}{|l|l|c|c|c|c|c|}
\hline Sr. & Ingredient & \multicolumn{4}{|c|}{ Formulation Codes } \\
\cline { 3 - 7 } No. & (mg) & F1 & F2 & F3 & F4 & F5 \\
\hline $\mathbf{1}$ & Terbinafine Hydrochloride & 250 & 250 & 250 & 250 & 250 \\
\hline $\mathbf{2}$ & Fluconazole & 150 & 150 & 150 & 150 & 150 \\
\hline $\mathbf{3}$ & Hydroxy propyl cellulose & 10 & 15 & 20 & 25 & 30 \\
\hline $\mathbf{4}$ & Starch (10\%w/w) & 50 & 50 & 50 & 50 & 50 \\
\hline $\mathbf{5}$ & Talc (1\%w/w) & 5 & 5 & 5 & 5 & 5 \\
\hline $\mathbf{6}$ & Magnesium Stearate (1\%w/w) & 5 & 5 & 5 & 5 & 5 \\
\hline $\mathbf{7}$ & Lactose & 35 & 30 & 25 & 20 & 15 \\
\hline & Weight of tablet & $\mathbf{5 0 0} \mathbf{~ m g}$ & $\mathbf{5 0 0} \mathbf{~} \mathbf{m g}$ & $\mathbf{5 0 0} \mathbf{~ m g}$ & $\mathbf{5 0 0} \mathbf{~ m g}$ & $\mathbf{5 0 0} \mathbf{~ m g}$ \\
\hline
\end{tabular}




\subsubsection{Evaluation of granules}

\subsubsection{Mean granule size}

Mean granule size was determined using electric sieve shaker (Eectrolab, Mumbai, India) in which different BSS were arranged in ascending order of sieve number $(16,22$, 44 and 60 ). Accurately weighed $30 \mathrm{~g}$ of granules was placed on the top sieve and sieve shaker was operated for $20 \mathrm{~min}$. The granules retained on each sieve were weighed and granules retained on each sieve were determined. The mean granule size was calculated by finding out the average size of the sieve opening, through which the granules were passed and the size of the sieve opening, on which the granules were retained. The weight retained (X) on each sieve was multiplied with average sieve opening $(\mathrm{Y})$ of two successive sieves. The mean granule size was determined using formula given below ${ }^{13}$.

\section{Mean granule size $(\mu \mathrm{m})=\Sigma X Y /$ Weight of granules}

\subsubsection{Bulk and tapped density}

Bulk density was measured by taking $35 \mathrm{ml}$ granules in 50 $\mathrm{ml}$ measuring cylinder. The granules volume at initial stage was recorded in the form of bulk volume. The placement of measuring cylinder was done on tapped density tester (EDT1020, Electro lab, India). The falling rate of drops was $250 /$ minutes from the height of $3 \mathrm{~mm} \pm 10 \%$. The volume of powder bed was recorded after every increase of 250 drops up to constant volume change. The final recorded volume was known as tapped volume. The BD and TD were measured as ratio of weight of the powder by bulk volume and tapped volume ${ }^{14}$.

\subsubsection{Determination of Hausner ratio}

Hausner ratio is an indirect index of ease of powder flow. Hausner ratio was calculated formula given below.

\section{Hausner ratio $=\mathrm{TD} / \mathrm{BD}$}

\subsubsection{Determination of Carr's consolidation index}

Carr's consolidation index was calculated by formula given below.

\section{Carr's consolidation index (\%) $=[(T D-B D) / T D] \times 100$}

\subsubsection{Determination of angle of repose}

Angle of repose acts as important parameter to determined the flow property of granule. Funnel was placed and fixed at above of graph paper, which was placed on horizontal flat surface. The granule was carefully poured through the funnel until the apex of the conical pile just touched tip of the funnel. The radius ( $\mathrm{r}$ ) of base of pile and height $(\mathrm{h})$ of the pile was determined. The angle of repose $(\theta)$ was calculated by using formula given below.

$$
\theta=\tan ^{-1} \mathbf{h} / \mathbf{r}
$$

\subsubsection{Percentage of fines}

For the determination of percentage fines, a known weight of dried granules was passed through BSS 44. The weight of granules which passed through sieve number 44 was recorded and percentage fine was calculated with respect to total weight of granules.

\subsubsection{Moisture content}

Moisture content (\%) of granules was determined using a digital moisture balance (MA45, Sartorius, Mumbai, India).

\subsubsection{Compression of FDC tablets}

The granules were compressed into $500 \mathrm{mg}$ tablets on a 10 station rotary tablet compression machine (Rimek, Ahmadabad, India) using $13 \mathrm{~mm}$ die cavity.

\subsubsection{Evaluation of FDC tablets}

\subsubsection{General Appearance}

The compressed tablets were observed for color, shape, surface irregularities, cracks or any other defects.

\subsubsection{Average weight}

Twenty tablets were weighed individually and the average weight was calculated. The individual tablet weights were then compared to the average weight and percent deviation was calculated.

\subsubsection{Thickness and Hardness}

The thicknesses of randomly selected 10 tablets were determined using digital vernier caliper (Mitutoya, Japan). Hardness of tablets $(n=10)$ for each batch was determined using Monsanto hardness tester (Cadmach, Ahmedabad, India).

\subsubsection{Determination of Friability}

Friability was determined using Roche friabilator (Electrolab). Initial weight of the 10 tablets was recorded (W1). The tablets were placed in the friabilator and rotated at $25 \mathrm{rpm}$ for four minutes. After that, tablets were taken out and final weight was determined (W2). The percentage friability was determined by using formula given below.

$$
\text { Friability }(\%)=[(\mathrm{W} 1-\mathrm{W} 2) / \mathrm{W} 1] \times 100
$$

\subsubsection{Disintegration time}

The disintegration time for tablets $(n=6)$ for $F 2, F 3, F 4$ and F5 was determined using disintegration test apparatus (ED2SAPO, Electrolab, India) at $37 \pm 0.5^{\circ} \mathrm{C}$ in $0.1 \mathrm{~N} \mathrm{HCl}$.

\subsubsection{Drug content}

Drug content of formulation F2 and F3 was determined. Average weight of 10 tablets was determined and then tablets were crushed to form powder. Powder having weight equivalent to average weight was taken in $100 \mathrm{ml}$ of volumetric flask and dissolved in small volume of $0.1 \mathrm{~N} \mathrm{HCl}$. Final volume was adjusted with $0.1 \mathrm{~N} \mathrm{HCl}$. Then the flask was shaken for $24 \mathrm{~h}$ using a water bath shaker and solution was filtered. After suitable dilution of filtrate, absorbance was measured at $222 \mathrm{~nm}$ and $239 \mathrm{~nm}$ for TH and FLZ, respectively using an UV-Visible spectrophotometer and drug content was calculated by Q-Analysis method.

\subsubsection{In vitro drug release}

In vitro drug release study of the tablets (F2 and F3) was performed using USP Type II dissolution test apparatus (LABINDIA DS 8000, India) using $900 \mathrm{ml} 0.1 \mathrm{~N} \mathrm{HCl}$ as a dissolution medium maintained at $37 \pm 0.5^{\circ} \mathrm{C}$. The paddles were rotated at speed of $75 \mathrm{rpm}$. At regular intervals of time for 1 hour, $10 \mathrm{ml}$ sample was withdrawn and replaced with equal volume of $0.1 \mathrm{~N} \mathrm{HCl}$ to maintain the sink condition. Samples were filtered through whatmann filter $(0.42 \mu \mathrm{m})$ paper and after appropriate dilutions absorbance was recorded at $222 \mathrm{~nm}$ and $239 \mathrm{~nm}$ for TH and FLZ, respectively using an UV-Visible spectrophotometer. The $\mathrm{T}_{80 \%}$ (Time to release $80 \%$ of drug) was calculated from percent cumulative drug release vs. time plots. 


\section{RESULTS}

\subsection{Preformualtion Studies}

TH was white, odourless and sticky powder while FLZ was almost white and odourless powder. The melting point of $\mathrm{TH}$ and FLZ was found to be $205.66 \pm 1.15^{\circ} \mathrm{C}$ and $139.66 \pm$ $0.57^{\circ} \mathrm{C}$, respectively. The absorption maxima of TH and FLZ were found at $222 \mathrm{~nm}$ and $260 \mathrm{~nm}$, respectively. The calibration curve of TH and FLZ in $0.1 \mathrm{~N} \mathrm{HCl}$ is shown in Fig. 1a and $\mathbf{1 b}$, respectively.

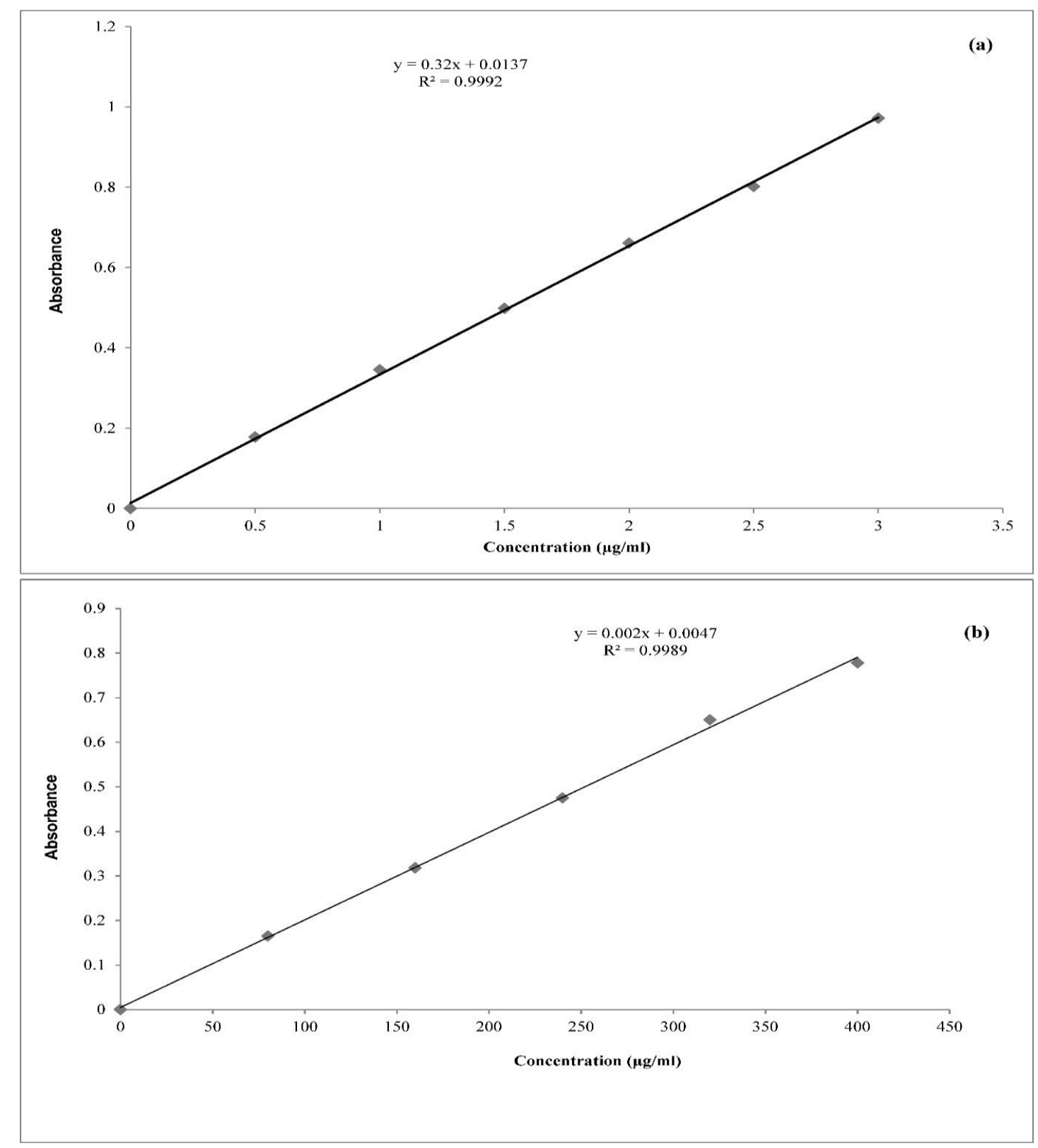

Fig. 1 Calibration curve (a) TH at $222 \mathrm{~nm}$ in $0.1 \mathrm{~N} \mathrm{HCl}$ (b) FLZ at $260 \mathrm{~nm}$ in $0.1 \mathrm{~N} \mathrm{HCl}$

The FTIR spectrum of TH (Fig. 2a) showed important peaks at $2869.54 \mathrm{~cm}^{-1}\left(-\mathrm{OH}\right.$ stretching), $2446.81 \mathrm{~cm}^{-1} \quad(-\mathrm{SH}$ stretching), $2224.98 \mathrm{~cm}^{-1}$ (-CN stretching), $1633.78 \mathrm{~cm}^{-1}$ ($\mathrm{C}=0$ stretching), $1469.82 \mathrm{~cm}^{-1}$ (-C-H bending), $1072.47 \mathrm{~cm}^{-1}$ $\left(-\mathrm{S}=0\right.$ stretching) and $777.35 \mathrm{~cm}^{-1}(-\mathrm{C}-\mathrm{Cl}$ stretching). The FTIR spectrum of FLZ (Fig. 2b) showed important peaks at $3120.96 \mathrm{~cm}^{-1}$ (OH stretching), $1211.35 \mathrm{~cm}^{-1}$ (C-F stretching), $1621.24 \mathrm{~cm}^{-1}\left(-\mathrm{C}=\mathrm{N}\right.$ stretching) and $2961.82 \mathrm{~cm}^{-1} \quad(-\mathrm{C}-\mathrm{H}$ stretching). The FTIR spectrum of drugs in combination (Fig. 2c) showed important peaks for TH at $2964.72 \mathrm{~cm}^{-1}(-$ OH stretching), $2446.81 \mathrm{~cm}^{-1}$ (-SH stretching), $2227.88 \mathrm{~cm}^{-1}$ (-CN stretching), $1621.24 \mathrm{~cm}^{-1}$ (-C=0 stretching), 1465.96 $\mathrm{cm}^{-1}$ (-C-H bending), $1076.33 \mathrm{~cm}^{-1}(-\mathrm{S}=0$ stretching) and
$773.21 \mathrm{~cm}^{-1}$ (-C-Cl stretching). The important peaks for FLZ were observed at $3119.99 \mathrm{~cm}^{-1}$ (OH stretching), $1210.38 \mathrm{~cm}$ 1 (C-F stretching), $1621.24 \mathrm{~cm}^{-1} \quad(-\mathrm{C}=\mathrm{N}$ stretching) and $2964.72 \mathrm{~cm}^{-1}$ (-C-H stretching). The FTIR spectrum of physical mixture of drugs with excipients used in formulation of FDC tablets (Fig. 2d) showed important peaks for TH at $2970.50 \mathrm{~cm}^{-1}$ (-OH stretching), $2447.77 \mathrm{~cm}^{-1}$ (-SH stretching), $2225.95 \mathrm{~cm}^{-1}$ (-CN stretching), $1622.20 \mathrm{~cm}^{-1}$ ($\mathrm{C}=0$ stretching), $1466.93 \mathrm{~cm}^{-1}$ (-C-H bending), $1078.07 \mathrm{~cm}^{-1}$ $\left(-\mathrm{S}=0\right.$ stretching) and $776.38 \mathrm{~cm}^{-1}$ (-C-Cl stretching). The important peaks for FLZ were observed at $3119.99 \mathrm{~cm}^{-1}(\mathrm{OH}$ stretching), $1208.46 \mathrm{~cm}^{-1}$ (C-F stretching), $1622.20 \mathrm{~cm}^{-1}$ ($\mathrm{C}=\mathrm{N}$ stretching) and $2970.50 \mathrm{~cm}^{-1}(-\mathrm{C}-\mathrm{H}$ stretching) 15 


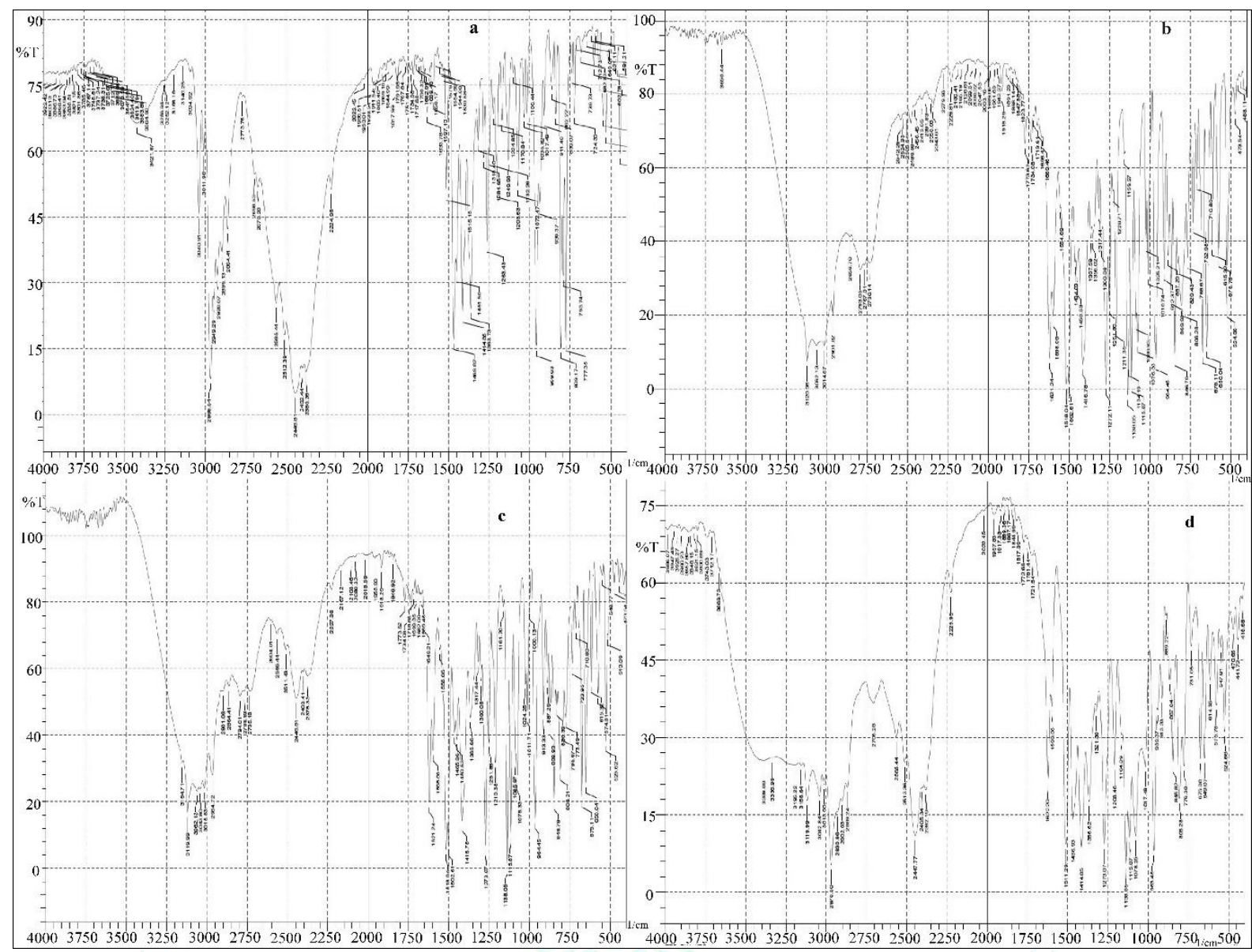

Fig 2. FTIR spectra (a) TH (b) FLZ (c) TH and FLZ physical mixture (d) Physical mixture of TH and FLZ with excipients in FDC tablets

3.2 Development and validation of simultaneous estimation method for TH and FLZ by UV-Visible spectrophotometer

The $\lambda_{\max }$ of $3 \mu \mathrm{g} / \mathrm{ml}$ solution of $\mathrm{TH}$ in $0.1 \mathrm{~N} \mathrm{HCl}$ was found to be $222 \mathrm{~nm}$. The $\lambda_{\max }$ of $400 \mu \mathrm{g} / \mathrm{ml}$ solution of FLZ in $0.1 \mathrm{~N} \mathrm{HCl}$ was found to be $260 \mathrm{~nm}$. In the overlay spectra (Fig. 3) three iso-absorptive points viz. $224 \mathrm{~nm}, 239 \mathrm{~nm}$ and $275 \mathrm{~nm}$ were reported and the iso-absorptive point $239 \mathrm{~nm}$ was selected for further analysis.

Linearity of TH was found in concentration range of 0.5-3.0 $\mu \mathrm{g} / \mathrm{ml}$ at $222 \mathrm{~nm}$ and $239 \mathrm{~nm}$ (Table 2, Fig. $\mathbf{4 a}$ and $\mathbf{4 b}$ ).
Linearity of FLZ was found in the concentration range 160$400 \mu \mathrm{g} / \mathrm{ml}$ at $222 \mathrm{~nm}$ and $239 \mathrm{~nm}$ (Table No. 2, Fig. 4c and 4d). The result of percent recovery study of proposed method is shown in Table 3 . The percent recovery of TH at $222 \mathrm{~nm}$ and $239 \mathrm{~nm}$ was found in the range of $100.17 \pm$ $0.0032 \%$ to $101.96 \pm 0.0026 \%$ and $98.50 \pm 0.0010 \%$ to $101.31 \pm 0.0006 \%$, respectively. The percent recovery of FLZ at $222 \mathrm{~nm}$ and $239 \mathrm{~nm}$ was found in the range of $98.27 \pm$ $0.3125 \%$ to $102.36 \pm 0.0210 \%$ and $100.57 \pm 0.4318 \%$ to $102.13 \pm 0.9174 \%$, respectively.

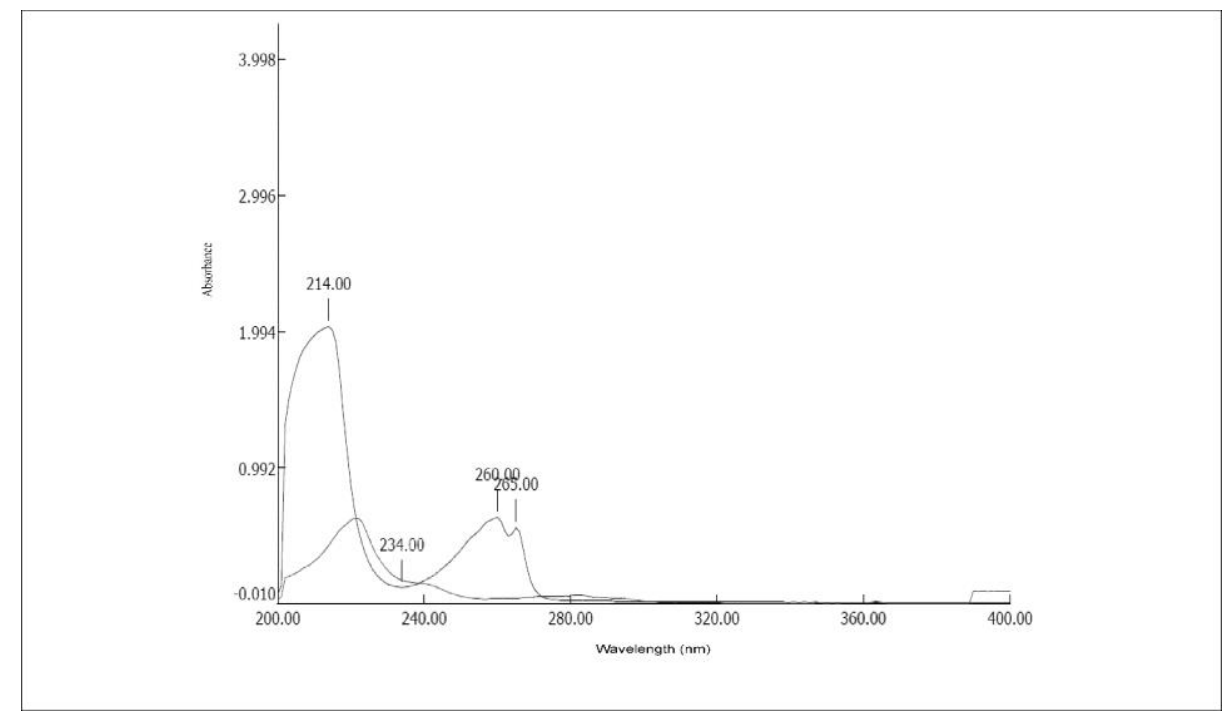

Fig. 3 Overlay spectrum of TH and FLZ in $0.1 \mathrm{~N} \mathrm{HCl}$ 
Table No. 2 Linearity data of TH and FLZ at $222 \mathrm{~nm}$ and $239 \mathrm{~nm}$ in $0.1 \mathrm{~N} \mathrm{HCl}$

\begin{tabular}{|l|l|l|l|l|l|l|}
\hline \multirow{2}{*}{ S.no } & \multicolumn{3}{|c|}{ TH } & \multicolumn{3}{c|}{ FLZ } \\
\cline { 2 - 7 } & $\begin{array}{l}\text { Concentration } \\
(\mu \mathrm{g} / \mathrm{ml})\end{array}$ & $\begin{array}{l}\text { Absorbance at } \\
\mathbf{2 2 2} \mathbf{~ n m}\end{array}$ & $\begin{array}{l}\text { Absorbance at } \\
\mathbf{2 3 9} \mathbf{~ n m}\end{array}$ & $\begin{array}{l}\text { Concentration } \\
(\mu \mathrm{g} / \mathrm{ml})\end{array}$ & $\begin{array}{l}\text { Absorbance at } \\
\mathbf{2 2 2} \mathbf{~ n m}\end{array}$ & $\begin{array}{l}\text { Absorbance at } \\
\mathbf{2 3 9} \mathbf{~ n m}\end{array}$ \\
\hline 1 & 0.5 & $0.178 \pm 0.0020$ & $0.035 \pm 0.0010$ & 160 & $0.265 \pm 0.0005$ & $0.065 \pm 0.0012$ \\
\hline 2 & 1.0 & $0.345 \pm 0.0010$ & $0.077 \pm 0.0015$ & 200 & $0.334 \pm 0.0012$ & $0.082 \pm 0.0012$ \\
\hline 3 & 1.5 & $0.498 \pm 0.0010$ & $0.102 \pm 0.0006$ & 240 & $0.431 \pm 0.0010$ & $0.105 \pm 0.0010$ \\
\hline 4 & 2.0 & $0.661 \pm 0.0020$ & $0.140 \pm 0.0012$ & 300 & $0.524 \pm 0.0005$ & $0.126 \pm 0.0005$ \\
\hline 5 & 2.5 & $0.802 \pm 0.0010$ & $0.178 \pm 0.0010$ & 360 & $0.628 \pm 0.0015$ & $0.154 \pm 0.0011$ \\
\hline 6 & 3.0 & $0.972 \pm 0.0010$ & $0.217 \pm 0.0012$ & 400 & $0.717 \pm 0.0012$ & $0.176 \pm 0.0015$ \\
\hline
\end{tabular}

Mean \pm SD; $n=3$

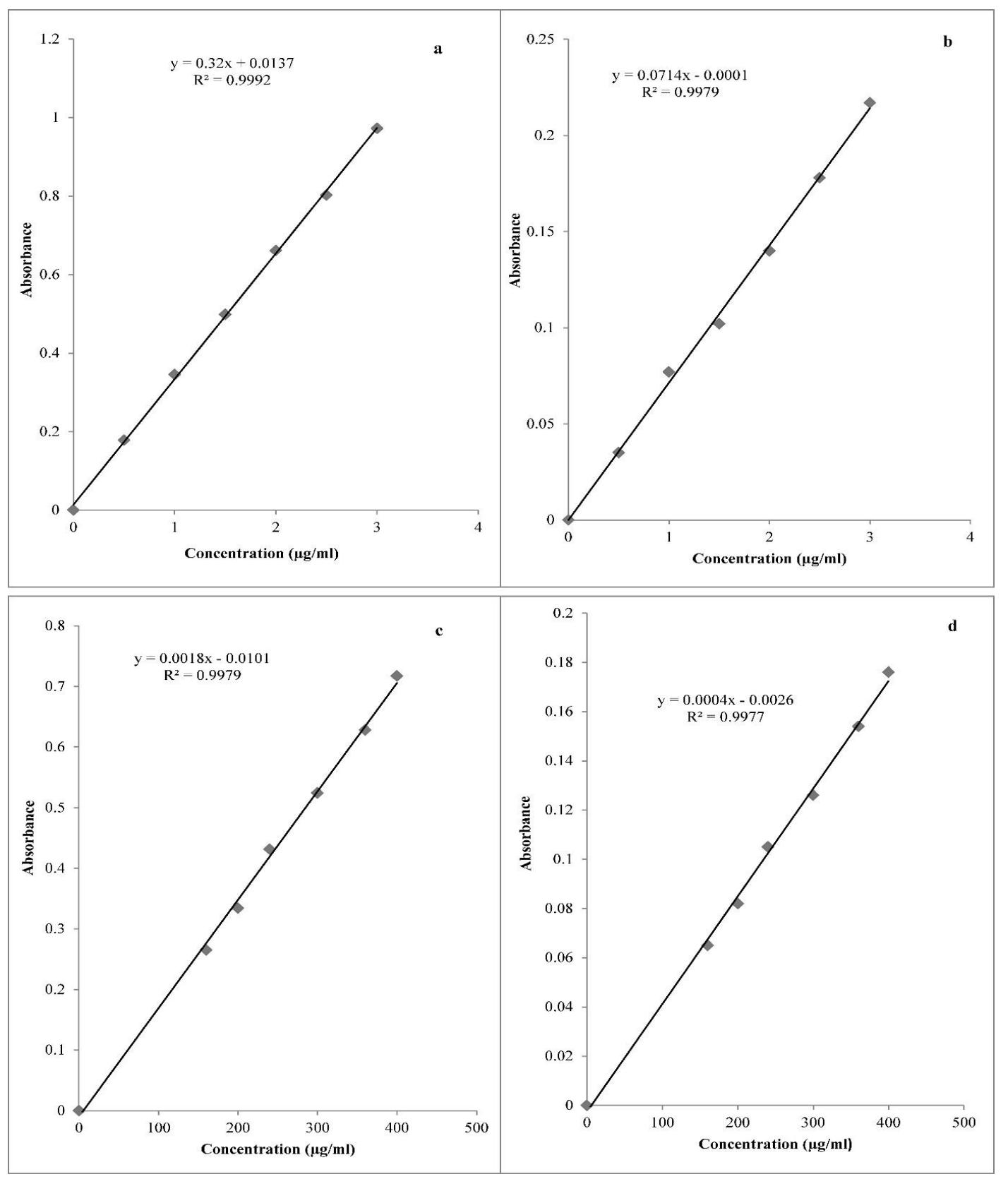

Fig. 4 Calibration curve (a) TH at $222 \mathrm{~nm}$ (b) TH at $239 \mathrm{~nm}$ (c) FLZ at $222 \mathrm{~nm}$ (d) FLZ at $239 \mathrm{~nm}$ 
Table No. 3 Percent recovery of TH and FLZ at $222 \mathrm{~nm}$ and $239 \mathrm{~nm}$ in $0.1 \mathrm{~N} \mathrm{HCl}$

\begin{tabular}{|c|c|c|c|c|c|c|c|c|c|}
\hline \multicolumn{5}{|c|}{ TH } & \multicolumn{5}{|c|}{ FLZ } \\
\hline \multirow{2}{*}{$\begin{array}{l}\text { Conc* } \\
(\mu \mathrm{g} / \mathrm{ml})\end{array}$} & \multicolumn{2}{|c|}{$222 \mathrm{~nm}$} & \multicolumn{2}{|c|}{$239 \mathrm{~nm}$} & \multirow{2}{*}{$\begin{array}{l}\text { Conc } \\
(\mu \mathrm{g} / \mathrm{ml})\end{array}$} & \multicolumn{2}{|c|}{$222 \mathrm{~nm}$} & \multicolumn{2}{|c|}{$239 \mathrm{~nm}$} \\
\hline & $\begin{array}{l}\text { Conc } \\
\text { found } \\
(\mu \mathrm{g} / \mathrm{ml})\end{array}$ & \% R & $\begin{array}{l}\text { Conc } \\
\text { found } \\
(\mu \mathrm{g} / \mathrm{ml})\end{array}$ & $\% \mathrm{R}$ & & $\begin{array}{l}\text { Conc found } \\
(\mu \mathrm{g} / \mathrm{ml})\end{array}$ & $\% \mathrm{R}$ & $\begin{array}{l}\text { Conc found } \\
(\mu \mathrm{g} / \mathrm{ml})\end{array}$ & $\% \mathrm{R}$ \\
\hline 2.0 & $\begin{array}{l}2.03 \pm \\
0.0057\end{array}$ & $\begin{array}{l}101.40 \pm \\
0.0360\end{array}$ & $\begin{array}{l}1.97 \pm \\
0.0026\end{array}$ & $\begin{array}{l}98.50 \pm \\
0.0010\end{array}$ & 240 & $\begin{array}{l}245.66 \pm \\
0.5946\end{array}$ & $\begin{array}{l}102.36 \pm \\
0.0210\end{array}$ & $\begin{array}{l}242.86 \pm \\
1.1335\end{array}$ & $\begin{array}{l}101.19 \pm \\
0.0316\end{array}$ \\
\hline 2.5 & $\begin{array}{l}2.5 \pm \\
0.0011\end{array}$ & $\begin{array}{l}100.17 \pm \\
0.0032\end{array}$ & $\begin{array}{l}2.51 \pm \\
0.0069\end{array}$ & $\begin{array}{l}100.31 \pm \\
0.0006\end{array}$ & 300 & $\begin{array}{l}302.55 \pm \\
0.6755\end{array}$ & $\begin{array}{l}100.85 \pm \\
0.0315\end{array}$ & $\begin{array}{l}301.71 \pm \\
0.5861\end{array}$ & $\begin{array}{l}100.57 \pm \\
0.4318\end{array}$ \\
\hline 3.0 & $\begin{array}{l}3.06 \pm \\
0.0208\end{array}$ & $\begin{array}{l}101.96 \pm \\
0.0026\end{array}$ & $\begin{array}{l}2.99 \pm \\
0.0549\end{array}$ & $\begin{array}{l}99.90 \pm \\
0.0017\end{array}$ & 360 & $\begin{array}{l}353.77 \pm \\
0.4229\end{array}$ & $\begin{array}{l}98.27 \pm \\
0.3125\end{array}$ & $\begin{array}{l}367.66 \pm \\
1.113\end{array}$ & $\begin{array}{l}102.13 \pm \\
0.9174\end{array}$ \\
\hline
\end{tabular}

Mean \pm SD; $n=3$, Conc $*=$ Concentration, $\% R^{\#}=$ Percent recovery

The result of intermediate precision study is shown in Table No. 4. In determination of precision by repeatability study, percent relative standard deviation (\%RSD) of TH at $222 \mathrm{~nm}$ and $239 \mathrm{~nm}$ was found to be 0.016 and 0.0193 , respectively.
Similarly, \% RSD of FLZ at $222 \mathrm{~nm}$ and $239 \mathrm{~nm}$ was found to be 0.481 and 0.0171 , respectively. The results of reproducibility study are shown in Table No. 5.

Table No. 4 Intermediate precision of TH and FLZ at $222 \mathrm{~nm}$ and $239 \mathrm{~nm}$ in $0.1 \mathrm{~N} \mathrm{HCl}$

\begin{tabular}{|c|c|c|c|c|c|c|c|c|c|}
\hline \multirow[t]{2}{*}{ Drug } & \multirow{2}{*}{$\begin{array}{l}\text { Concentration } \\
(\mu \mathrm{g} / \mathrm{ml})\end{array}$} & \multicolumn{4}{|c|}{ Absorbance at $222 \mathrm{~nm}$} & \multicolumn{4}{|c|}{ Absorbance at $239 \mathrm{~nm}$} \\
\hline & & Inter-day & \% RSD & Intra-day & $\%$ RSD & Inter-day & \% RSD & Intra-day & $\%$ RSD \\
\hline \multirow{3}{*}{ TH } & 2.0 & $\begin{array}{l}0.641 \pm \\
0.0031\end{array}$ & 0.483 & $\begin{array}{l}0.646 \pm \\
0.0017\end{array}$ & 0.216 & $\begin{array}{l}0.146 \pm \\
0.0012\end{array}$ & 0.822 & $\begin{array}{l}0.144 \pm \\
0.0010\end{array}$ & 0.694 \\
\hline & 2.5 & $\begin{array}{l}0.790 \pm \\
0.0015\end{array}$ & 0.189 & $\begin{array}{l}0.790 \pm \\
0.0045\end{array}$ & 0.569 & $\begin{array}{l}0.181 \pm \\
0.0012\end{array}$ & 0.662 & $\begin{array}{l}0.182 \pm \\
0.0035\end{array}$ & 0.019 \\
\hline & 3.0 & $\begin{array}{l}0.917 \pm \\
0.0031\end{array}$ & 0.338 & $\begin{array}{l}0.911 \pm \\
0.0064\end{array}$ & 0.702 & $\begin{array}{l}0.216 \pm \\
0.0006\end{array}$ & 0.277 & $\begin{array}{l}0.217 \pm \\
0.0010\end{array}$ & 0.555 \\
\hline \multirow{3}{*}{ FLZ } & 240 & $\begin{array}{l}0.450 \pm \\
0.0023\end{array}$ & 0.511 & $\begin{array}{l}0.454 \pm \\
0.0021\end{array}$ & 0.465 & $\begin{array}{l}0.104 \pm \\
0.0006\end{array}$ & 0.576 & $\begin{array}{l}0.108 \pm \\
0.0006\end{array}$ & 0.555 \\
\hline & 300 & $\begin{array}{l}0.562 \pm \\
0.0015\end{array}$ & 0.267 & $\begin{array}{l}0.556 \pm \\
0.0010\end{array}$ & 0.180 & $\begin{array}{l}0.129 \pm \\
0.00058\end{array}$ & 0.387 & $\begin{array}{l}0.127 \pm \\
0.0012\end{array}$ & 0.945 \\
\hline & 360 & $\begin{array}{l}0.658 \pm \\
0.0023\end{array}$ & 0.349 & $\begin{array}{l}0.656 \pm \\
0.0015\end{array}$ & 0.229 & $\begin{array}{l}0.154 \pm \\
0.0012\end{array}$ & 0.779 & $\begin{array}{l}0.152 \pm \\
0.0010\end{array}$ & 0.658 \\
\hline
\end{tabular}

Mean \pm SD; $n=3$

Table No. 5 Reproducibility of TH and FLZ at $222 \mathrm{~nm}$ and $239 \mathrm{~nm}$ in $0.1 \mathrm{~N} \mathrm{HCl}$

\begin{tabular}{|c|c|c|c|c|c|c|c|c|c|}
\hline \multirow[t]{2}{*}{ Drug } & \multirow{2}{*}{$\begin{array}{c}\text { Concentration } \\
(\mu \mathrm{g} / \mathrm{ml})\end{array}$} & \multicolumn{4}{|c|}{ Absorbance at $222 \mathrm{~nm}$} & \multicolumn{4}{|c|}{ Absorbance at $239 \mathrm{~nm}$} \\
\hline & & $\begin{array}{c}\text { Analyst } \\
1\end{array}$ & $\begin{array}{c}\text { Analyst } \\
2\end{array}$ & $\begin{array}{l}\text { Calc. ' } t \text { ' } \\
\text { value }\end{array}$ & Inference & $\begin{array}{c}\text { Analyst } \\
1\end{array}$ & $\begin{array}{c}\text { Analyst } \\
2\end{array}$ & $\begin{array}{l}\text { Calc. ' } t \text { ' } \\
\text { value }\end{array}$ & Inference \\
\hline $\mathrm{TH}$ & 2.0 & $\begin{array}{c}0.643 \pm \\
0.0015\end{array}$ & $\begin{array}{c}0.646 \pm \\
0.0030\end{array}$ & 0.8857 & $\begin{array}{c}\text { No } \\
\text { significant } \\
\text { difference }\end{array}$ & $\begin{array}{c}0.145 \pm \\
0.038\end{array}$ & $\begin{array}{c}0.149 \pm \\
0.0035\end{array}$ & 0.4000 & $\begin{array}{c}\text { No } \\
\text { significant } \\
\text { difference }\end{array}$ \\
\hline FLZ & 300 & $\begin{array}{l}0.566 \pm \\
0.0020\end{array}$ & $\begin{array}{l}0.565 \pm \\
0.0040\end{array}$ & 0.8000 & $\begin{array}{c}\text { No } \\
\text { significant } \\
\text { difference }\end{array}$ & $\begin{array}{l}0.126 \pm \\
0.0025\end{array}$ & $\begin{array}{l}0.128 \pm \\
0.0026\end{array}$ & 0.5066 & $\begin{array}{c}\text { No } \\
\text { significant } \\
\text { difference }\end{array}$ \\
\hline
\end{tabular}

\section{Mean \pm SD; $\mathbf{n}=3$, *Calc. $=$ Calculated}

The LOD of TH at $222 \mathrm{~nm}$ and $239 \mathrm{~nm}$ was found to be 0.067 and $0.175 \mu \mathrm{g} / \mathrm{ml}$, respectively. The LOD of FLZ at $222 \mathrm{~nm}$ and $239 \mathrm{~nm}$ was found to be 31.09 and $94.38 \mu \mathrm{g} / \mathrm{ml}$, respectively. The LOQ of $\mathrm{TH}$ at $222 \mathrm{~nm}$ and $239 \mathrm{~nm}$ was found to be 0.203 and $0.531 \mu \mathrm{g} / \mathrm{ml}$, respectively. The LOD of FLZ at $222 \mathrm{~nm}$ and $239 \mathrm{~nm}$ was found to be 94.21 and $286.00 \mu \mathrm{g} / \mathrm{ml}$, respectively. 


\subsection{Formulation and evaluation of FDC tablets}

The results of evaluation of pre-compression parameters viz. mean granule size, tapped density, bulk density, Hausner's ratio, Carr's consolidation index, angle of repose, percent fines and percent moisture content of granules is shown in Table No. 6. The results of post-compression parameters viz. appearance, average weight, thickness, hardness, percent friability, disintegration time and drug content is shown in Table No. 7. The result of in vitro drug release study of the formulations is shown in Table No. 8 and Fig. 5. The $\mathrm{T}_{80 \%}$ of TH and FLZ in F2 was found to be 11 and 10.5 minutes, respectively. The $\mathrm{T}_{80 \%}$ of $\mathrm{TH}$ and FLZ in F3 was found to be 12 and 11.5 minutes, respectively.

Table No. 6 Pre-compression parameter of granules formulated using HPC as binder

\begin{tabular}{|c|c|c|c|c|c|c|c|c|}
\hline $\begin{array}{c}\text { Formu- } \\
\text { lation } \\
\text { code }\end{array}$ & $\begin{array}{c}\text { Average } \\
\text { granule } \\
\mathbf{s i z e} \\
\mathbf{( \mu \mathrm { m } )}\end{array}$ & $\begin{array}{c}\text { Loose bulk } \\
\mathbf{d e n s i t y} \\
\mathbf{( g / m )}\end{array}$ & $\begin{array}{c}\text { Tapped bulk } \\
\mathbf{d e n s i t y} \\
\mathbf{( g / m l )}\end{array}$ & $\begin{array}{c}\text { Hausner's } \\
\text { ratio }\end{array}$ & $\begin{array}{c}\text { Carr's } \\
\text { consolidation } \\
\text { index (\%) }\end{array}$ & $\begin{array}{c}\text { Angle of } \\
\text { repose (⿳) }\end{array}$ & $\begin{array}{c}\text { Fines } \\
\mathbf{( \% )}\end{array}$ & $\begin{array}{c}\text { Moisture } \\
\text { content } \\
\mathbf{( \% )}\end{array}$ \\
\hline F1 & $312.256 \pm$ & $0.574 \pm$ & $0.634 \pm$ & $1.233 \pm$ & $18.883 \pm$ & $26.61 \pm$ & $10.611 \pm$ & $1.584 \pm$ \\
& 0.600 & 0.005 & 0.008 & 0.002 & 0.142 & 0.824 & 0.067 & 0.031 \\
\hline F2 & $320.447 \pm$ & $0.478 \pm$ & $0.588 \pm$ & $1.212 \pm$ & $17.523 \pm$ & $25.68 \pm$ & $9.381 \pm$ & $1.815 \pm$ \\
& 0.511 & 0.004 & 0.012 & 0.004 & 0.283 & 0.813 & 0.160 & 0.035 \\
\hline F3 & $340.676 \pm$ & $0.468 \pm$ & $0.566 \pm$ & $1.208 \pm$ & $17.200 \pm$ & $23.79 \pm$ & $6.245 \pm$ & $1.642 \pm$ \\
& 0.956 & 0.007 & 0.011 & 0.003 & 0.235 & 0.376 & 0.068 & 0.059 \\
\hline F4 & $366.133 \pm$ & $0.437 \pm$ & $0.520 \pm$ & $1.189 \pm$ & $15.960 \pm$ & $21.81 \pm$ & $5.137 \pm$ & $1.593 \pm$ \\
& 0.653 & 0.003 & 0.005 & 0.004 & 0.173 & 0.306 & 0.069 & 0.049 \\
\hline F5 & $397.693 \pm$ & $0.407 \pm$ & $0.476 \pm$ & $1.169 \pm$ & $14.427 \pm$ & $20.28 \pm$ & $2.181 \pm$ & $1.948 \pm$ \\
& 1.223 & 0.035 & 0.008 & 0.010 & 0.837 & 0.220 & 0.035 & 0.005 \\
\hline
\end{tabular}

Mean \pm SD; $\mathbf{n}=3$

Table No. 7 Post compression parameters of FDC tablets formulated using HPC as binder

\begin{tabular}{|c|c|c|c|c|c|c|c|}
\hline \multirow{2}{*}{$\begin{array}{l}\text { Formulation } \\
\text { Code }\end{array}$} & \multirow{2}{*}{$\begin{array}{l}\text { Average } \\
\text { weight }(\mathrm{g}) *\end{array}$} & \multirow{2}{*}{$\begin{array}{l}\text { Thickness } \\
\text { (mm)** }\end{array}$} & \multirow{2}{*}{$\begin{array}{l}\text { Hardness } \\
\left(\mathrm{kg} / \mathrm{cm}^{2}\right)^{* *}\end{array}$} & \multirow{2}{*}{$\begin{array}{l}\text { Friability } \\
(\%)^{\#}\end{array}$} & \multirow{2}{*}{$\begin{array}{l}\text { Disintegration } \\
\text { time (min)\#\# }\end{array}$} & \multicolumn{2}{|c|}{ Drug content $(\%)^{\#}$} \\
\hline & & & & & & TH & FLZ \\
\hline F1 & $\begin{array}{l}496.12 \\
\pm 0.0084\end{array}$ & $\begin{array}{l}4.03 \\
\pm 0.020\end{array}$ & $\begin{array}{l}4.67 \\
\pm 0.777\end{array}$ & $\begin{array}{l}1.145 \\
\pm 0.039\end{array}$ & - & - & - \\
\hline F2 & $\begin{array}{l}502.34 \\
\pm 0.0067\end{array}$ & $\begin{array}{l}4.03 \\
\pm 0.011\end{array}$ & $\begin{array}{l}6.72 \\
\pm 0.006\end{array}$ & $\begin{array}{l}0.786 \\
\pm 0.069\end{array}$ & $\begin{array}{l}07.21 \\
\pm 0.333\end{array}$ & $\begin{array}{l}100.01 \\
\pm 0.318\end{array}$ & $\begin{array}{r}102.94 \\
\pm 0.329\end{array}$ \\
\hline F3 & $\begin{array}{l}503.01 \\
\pm 0.0070\end{array}$ & $\begin{array}{l}4.02 \\
\pm 0.012\end{array}$ & $\begin{array}{l}7.01 \\
\pm 0.012\end{array}$ & $\begin{array}{l}0.674 \\
\pm 0.006\end{array}$ & $\begin{array}{l}10.45 \\
\pm 0.436\end{array}$ & $\begin{array}{l}97.61 \\
\pm 0.300\end{array}$ & $\begin{array}{l}100.48 \\
\pm 0.323\end{array}$ \\
\hline F4 & $\begin{array}{l}502.24 \\
\pm 0.0067\end{array}$ & $\begin{array}{l}4.01 \\
\pm 0.009\end{array}$ & $\begin{array}{l}8.23 \\
\pm 0.306\end{array}$ & $\begin{array}{l}0.645 \\
\pm 0.051\end{array}$ & $\begin{array}{l}18.38 \\
\pm 0.141\end{array}$ & - & - \\
\hline F5 & $\begin{array}{l}504.21 \\
\pm 0.0057\end{array}$ & $\begin{array}{l}3.99 \\
\pm 0.012\end{array}$ & $\begin{array}{l}8.91 \\
\pm 0.200\end{array}$ & $\begin{array}{l}0.556 \\
\pm 0.034\end{array}$ & $\begin{array}{l}21.32 \\
\pm 0.156\end{array}$ & - & - \\
\hline
\end{tabular}

Mean $\pm S D, * n=20, * * n=10,{ }^{*} n=3,{ }^{\# \# n=6}$

Table No. 8 In vitro drug release of FDC tablets formulated using HPC as binder

\begin{tabular}{|c|c|c|}
\hline \multirow{2}{*}{ Time (min) } & \multicolumn{2}{|c|}{ Cumulative drug release (\%) } \\
\cline { 2 - 3 } & F2 & F3 \\
\hline $\mathbf{0}$ & 0 & 0 \\
\hline $\mathbf{1 0}$ & $77.32 \pm 2.597$ & $75.30 \pm 2.352$ \\
\hline $\mathbf{2 0}$ & $88.66 \pm 3.001$ & $86.41 \pm 1.464$ \\
\hline $\mathbf{3 0}$ & $97.62 \pm 2.421$ & $91.32 \pm 3.241$ \\
\hline $\mathbf{4 0}$ & $99.93 \pm 1.276$ & $99.62 \pm 2.353$ \\
\hline $\mathbf{5 0}$ & - & - \\
\hline $\mathbf{6 0}$ & - & - \\
\hline
\end{tabular}

Mean \pm SD, $n=3$ 


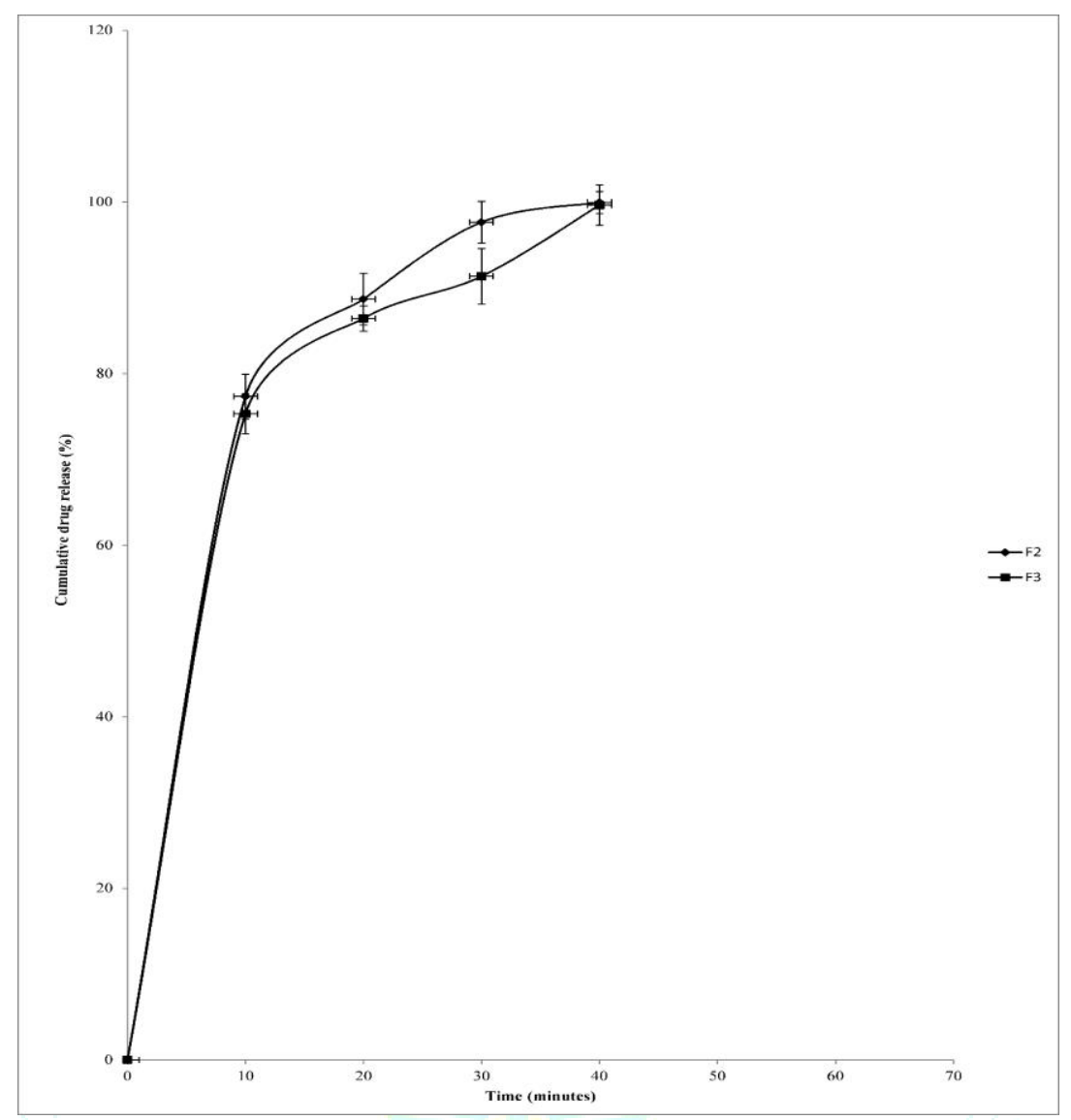

Fig. 5 Cumulative percent release of TH and FLZ from FDC tablets

\section{DISCUSSION}

\subsection{Preformulation studies}

The results of melting point determination of TH and FLZ indicated the purity of drug samples. The melting range of $\mathrm{TH}$ and FLZ reported in literature is $204-207^{\circ} \mathrm{C}$ and 138 $140^{\circ} \mathrm{C}$, respectively.

There was no major shift in the observed and standard peak positions of different functional groups in pure drug samples, indicating the purity of drug samples. Further, there was also no major change in the peak positions of different functional groups in FTIR spectrum of TH-FLZ physical mixture and TH-FLZ physical mixture with excipients as compared to the FTIR spectrum of pure drugs. Hence, The TH and FLZ together, and with the excipients used in tablet formulation were compatible.

\subsection{Development and validation of simultaneous estimation method for TH and FLZ by UV-Visible spectrophotometer}

The correlation coefficients of representative linear equations of TH and FLZ indicated very good linearity at 222 $\mathrm{nm}$ and $239 \mathrm{~nm}$. Good accuracy of the developed method was pointed out by the good percent recovery. The \%RSD values $(<2)$ in determination of intermediate precision and repeatability indicated good precision of proposed method [9]. There was no significant difference in the determination performed by two different analysts indicating good reproducibility of proposed method. The LOD and LOQ values of TH and FLZ on different wavelengths indicated good sensitivity of proposed method [9].

\subsection{Evaluation of granules}

The mean granule size increased with increased binder concentration. This might be because of better cohesion of solid mass due to improved wetting at higher binder concentration. The granules loose bulk density and tapped bulk density decreased with increased concentration of binder. This might be attributed to the increase average granule size with increased binder concentration.

Hausner's ratio is parameter that may be correlated to the flow property of granules. A value of angle of repose $\leq 1.25$ indicates good flow and a value $>1.25$ indicates poor flow. The Hausner's ratio decreased with increased binder concentrations. This might be because of increased mean granule size. All the formulations showed good flow property. Carr's consolidation index is related to the flow rate, cohesiveness and particle size of granules. Values below $15 \%$ represent good flow, 15 to $25 \%$ is fair/passable and values above $25 \%$ are indicative of poor flow. The F5 showed good whereas all the others formulation showed fair/passable flow property. Angle of repose also gives an idea of flow properties of granules. The angle of repose decreased with increased binder concentration, which indicated an improvement in flow. The increased granule size with increased binder concentrations might be the reason for this change. All the formulations were good flow properties 16 .

The percentage fines decreased with increased binder concentration which might be due to the better cohesion of solid mass at higher binder concentrations. The 1-2\% of moisture content is necessary for compression of granules into tablets. If moisture content of granules is below $1 \%$ the tablets tends to break or laminate after compression 17 . 


\subsection{Evaluation of FDC tablets}

The tablets were smooth, white, odorless and free from cracks or other surface irregularities. Average weight of tablets was found in between the range of $496.12 \pm 0.0084$ $\mathrm{mg}$ to $504.21 \pm 0.0057 \mathrm{mg}$ and thickness of tablets was found between the ranges of $3.99 \pm 0.200 \mathrm{~mm}$ to $4.033 \pm$ $0.200 \mathrm{~mm}$, respectively (Table 7).

The hardness and percent friability of the tablets increased and decreased, respectively with increased binder concentration. The percent friability of $\mathrm{F} 1$ was more than $1 \%$. Since, $\mathrm{F} 1$ failed in percent friability test, it was not considered for further evaluation. The disintegration time of the formulations increased with increased binder concentration. The disintegration time of formulation F2 and F3 was below 15 minutes and were considered for in vitro drug release study.

The drug content of F2 and F3 was found to be satisfactory. The rate of drug release decreased with increased binder concentration. The Indian pharmacopoeia states that uncoated conventional tablets should release $80 \%$ of drug within 30 min. Formulations F2 and F3 complies with the Indian Pharmacopoeia standard.

\section{CONCLUSION}

The developed FDC tablets can be a better alternative for treatment of $C$. albicans resistant to fluconazole. The TH and FLZ were compatible to each other and with the excipients used in the formulation of FDC tablet. The UV-visible spectrophotometric method developed for the simultaneous estimation of TH and FLZ was simple, accurate and sensitive. Further, the development of FDC tablets with other suitable pharmaceutical excipients and determination of synergistic effect in vitro or in vivo could be a future prospect for the developed FDC tablets.

\section{CONFLICT OF INTEREST}

The authors declare no conflict of interest, financial or otherwise

\section{ACKNOWLEDGEMENTS}

The author would like to acknowledge Dr. Manish Sinha, Head of Department, Department of Pharmaceutical Analysis \& Quality Assurance, Laureate Institute of Pharmacy for his valuable suggestions in the $\mathrm{Q}$-analysis method development for TH and FLZ.

\section{REFERENCES}

1. Martin VM. The use of fluconazole and itracinazole in the treatment of candida albicans infection: a review. Journal of Antimicrobial Chemotherapy. 1999; 44(4):429-437.
2. Shield BE, Rosenbach M, Brown-Joel Z, Berger AP, FordBA and Wanat KA. Angioinvasive fungal infections impacting the skin. Journal of the American Academy of Dermatology. 2019 1993; 869-880.

3. Barchiesi F, Morbiducci V, Ancarani F, Scalise G. Emergence of oropharyngeal candidiasis caused by non-albicans species of Candida in HIV-infected patients. European Journal of Epidemiology. 1993; 9(4):455-456.

4. Powderly WG, Robinson K, Keath EJ. Molecular epidemiology of recurrent oral candidiasis in human immunodeficiency virus-positive patients: evidence for two patterns of recurrence. The Journal of Infectious Diseases. 1993; 168(2):463-466.

5. Barchiesi F, Hollis R J, McGough DA, Scalise G, Rinaldi MG, Pfaller MG. DNA subtypes and fluconazole susceptibilities of Candida albicans isolates from the oral cavities of patients with AIDS. Clincal Infectious Diseases. 1995: 20(3):634-640.

6. Barchiesi F, Najvar LK, Luther MF, Scalise G, Rinaldi MG, Graybill JR. Variation in fluconazole efficacy for Candida albicans strains sequentially isolated from oral cavities of patients with AIDS in an experimental murine candidiasis model. Antimicrobial Agents and Chemotherapy. 1996; 40(5):1317-1320.

7. Ghonnoum AM, Elewski B. Successful treatment of fluconazole-resistant oropharyngeal candidiasis by a combination of fluconazole and terbinafine. Clinical and Diagnostic Laboratory Immunology. 1999; 6(6):6921-6923.

8. Barchiesi F, Di Francesco LF, Scalise G. In vitro activities of terbinafine in combination with fluconazole and itraconazole against isolates of Candida albicans with reduced susceptibility to Azoles. Antimicrobial Agents and Chemotherapy. 1997; 41(8):1812-1814.

9. Ugurlin $\mathrm{T}$, Ozaydin $\mathrm{T}$. An overview on fixed dose combinations. Asian Journal of Pharmceutical Technology and Innovation. 2014; 2(4):75-81.

10. Pandey G, Mishra B. A new analytical Q-absorbance ratio method-Development and validation for simultaneous estimation method for lamivudine and isoniazid. ISRN spectroscopy. 2013; 1:1-5.

11. Validation of analytical procedures: Text and methodology Q2 (R1). ICH Harmonised Tripartite Guideline. 2005: 1-13.

12. Venkatachalam T, Lalitha KG. Spectrophotometric methods for simultaneous estimation of melatonin and Zolpidem from the combined tablet dosage form. Pharmacophore. 2014; 5(2):252-257.

13. Martin A, Swarbrick J, Cammarata, A. Physical pharmacy. $3^{\text {rd }}$ ed. Mumbai: Varghese publishing house; 1991. P. 492-520.

14. United State Pharmacopoeia. 24th Asain ed. Tata Donnelly Limited, 2000.

15. Pavia DL, Lampman GM, Kriz GS, Vyvyan JR. Spectros-copy. 9th ed. Cengage Learning New Delhi, 2011.

16. Well J. Pharmaceutical preformulation. In: The science of dosage form design, Aulton ME, Ed; Toronto: Churchill Livingstone, 2003: 2nd ed, P. 113-138.

17. Lachman L, Lieberman HA, Kanig JL. Ed; Mumbai: Varghese publishing house; 1991. P. 293-345. 